\title{
Review \\ The Mechanism of Secretion and Metabolism of Gut-Derived 5-Hydroxytryptamine
}

\author{
Ning Liu ${ }^{1,2,3,+}$, Shiqiang Sun ${ }^{4,5,+}$, Pengjie Wang ${ }^{2,3} \oplus$, Yanan Sun ${ }^{2,3}$, Qingjuan $\mathrm{Hu}^{2,3}$ and Xiaoyu Wang ${ }^{1, *}$ \\ 1 Key Laboratory of Precision Nutrition and Food Quality, College of Food Science and Nutritional Engineering, \\ China Agricultural University, Beijing 100083, China; nuli982390@163.com \\ 2 Department of Nutrition and Health, China Agricultural University, Beijing 100193, China; \\ Wpj1019@cau.edu.cn (P.W.); 15153515695@163.com (Y.S.); wshqlsh@163.com (Q.H.) \\ 3 Beijing Advanced Innovation Center for Food Nutrition and Human Health, China Agricultural University, \\ Beijing 100193, China \\ 4 Department of Gastroenterology and Hepatology, University Medical Center Groningen, University of \\ Groningen, 9713ZG Groningen, The Netherlands; sqsun@hotmail.com \\ 5 Department of Genetics, University Medical Center Groningen, University of Groningen, \\ 9713ZG Groningen, The Netherlands \\ * Correspondence: xy.wang@cau.edu.cn; Tel.: +86-10-6273-8589 \\ + These authors contributed equally to this work.
}

Citation: Liu, N.; Sun, S.; Wang, P.; Sun, Y.; Hu, Q.; Wang, X. The

Mechanism of Secretion and Metabolism of Gut-Derived 5-Hydroxytryptamine. Int. J. Mol. Sci. 2021, 22, 7931. https://doi.org/ $10.3390 /$ ijms 22157931

Academic Editors: Hisamitsu Ishihara and Burkhard Poeggeler

Received: 30 April 2021

Accepted: 19 June 2021

Published: 25 July 2021

Publisher's Note: MDPI stays neutral with regard to jurisdictional claims in published maps and institutional affiliations.

Copyright: (C) 2021 by the authors. Licensee MDPI, Basel, Switzerland. This article is an open access article distributed under the terms and conditions of the Creative Commons Attribution (CC BY) license (https:// creativecommons.org/licenses/by/ $4.0 /)$.

\begin{abstract}
Serotonin, also known as 5-hydroxytryptamine (5-HT), is a metabolite of tryptophan and is reported to modulate the development and neurogenesis of the enteric nervous system, gut motility, secretion, inflammation, sensation, and epithelial development. Approximately 95\% of 5 -HT in the body is synthesized and secreted by enterochromaffin (EC) cells, the most common type of neuroendocrine cells in the gastrointestinal (GI) tract, through sensing signals from the intestinal lumen and the circulatory system. Gut microbiota, nutrients, and hormones are the main factors that play a vital role in regulating 5-HT secretion by EC cells. Apart from being an important neurotransmitter and a paracrine signaling molecule in the gut, gut-derived 5-HT was also shown to exert other biological functions (in autism and depression) far beyond the gut. Moreover, studies conducted on the regulation of 5-HT in the immune system demonstrated that 5-HT exerts anti-inflammatory and proinflammatory effects on the gut by binding to different receptors under intestinal inflammatory conditions. Understanding the regulatory mechanisms through which 5HT participates in cell metabolism and physiology can provide potential therapeutic strategies for treating intestinal diseases. Herein, we review recent evidence to recapitulate the mechanisms of synthesis, secretion, regulation, and biofunction of 5-HT to improve the nutrition and health of humans.
\end{abstract}

Keywords: 5-hydroxytryptamine; serotonin; secretion; metabolism

\section{Introduction}

Serotonin, or 5-Hydroxytryptamine (5-HT), a metabolite of tryptophan (Trp), is an important gastrointestinal (GI) regulatory factor with a wide range of physiological effects on humans and animals [1-4]. Approximately $95 \%$ of $5-\mathrm{HT}$ in the body is synthesized and secreted by enterochromaffin (EC) cells in the GI tract. Once 5-HT is released into the lamina propria, it is taken up by the epithelial cells through the serotonin reuptake transporter (SERT). Next, 5-HT diffuses into the bloodstream, where it is taken up by platelets and transported to peripheral target tissues. The physiological effects of 5-HT have been considerably investigated, and 5-HT has been reported to play a crucial role in GI regulation, particularly in intestinal motility and secretion [2]. The role of 5-HT in gut inflammation has also been widely investigated [4-7]. An increased concentration of 5-HT in the mucosa contributes to severe colitis. Serotonin has been shown to exert anti-inflammatory and proinflammatory effects on the gut by binding to different 5-HT 
receptors in animal models of inflammatory bowel disease (IBD) and colitis [8]. New clues have demonstrated that 5-HT exerts an anti-inflammatory effect on the gut by regulating the expression of the 5-HT4 receptor, with beneficial effects on intestinal epithelial cell barrier functions [4].

EC cells, which are specialized enteroendocrine (EE) cells that reside alongside the epithelium lining the lumen of the digestive tract, can synthesize and secrete 5-HT [9-13]. As a chemosensor, EC cells convert physiological and chemical signals from the lumen into biochemical endocrine signals through microvilli extending into the lumen and enzymes and transporters stored in the apical parts of the enterocytes. Importantly, 5-HT secretion in the gut is influenced by various factors such as nutrients, microbial community, hostderived signaling hormones, and peptides, which in turn directly or indirectly affect immune responses, nutrient metabolism, and intestinal homeostasis [14-16].

Gut-derived 5-HT and its various biological functions are receiving great interest from investigators. Gut-derived 5-HT possesses a range of protective effects, such as modulating gut motility and secretion, gut inflammation, liver regeneration, metabolic homeostasis, and bone remodeling, etc. This review aims to elucidate the functional role of 5-HT in and beyond the gut. We also provide an in-depth review highlighting the understanding of various factors (gut microbiota, nutrition, and hormones) in the regulation of 5-HT secretion. We hope that this review could lay a theoretical foundation for the application of 5-HT in nutrition, clinical medicine, and health.

\section{Synthesis and Secretion of Gut-Derived 5-HT}

\subsection{5-HT Synthesis}

Only 20 of more than 700 amino acids (AAs) in nature are building blocks for proteins in cells and traditionally categorized as nutritionally essential or nonessential for humans and animals on the basis of growth or nitrogen balance $[17,18]$. Trp is one of nine nutritionally essential AAs [19]. In addition to its role as a substrate for protein synthesis, Trp is an important precursor for many compounds such as 5-HT, melatonin, and kynurenine [20]. Correspondingly, Trp and its metabolites play a key role in nutrition, reproduction, immune system, and anti-stress responses [21-27]. The kynurenine and 5-HT pathways are two main metabolic routes for Trp metabolism in mammals. Approximately $95 \%$ of the ingested Trp is degraded into kynurenine, kynurenic acid, xanthurenic acid, quinolinic acid, and picolinic acid through the kynurenine pathway. Additionally, approximately $1-2 \%$ of the ingested Trp is degraded into 5-HT and melatonin through the 5-HT pathway [28]. There are two major synthetic routes of 5-HT in the brain stem and peripheral neurons. Moreover, approximately $95 \% 5-\mathrm{HT}$ in human body is synthesized in the peripheral system, especially in the GI tract [3,29]. Serotonergic neurons of the enteric nervous system and EC cells are two separate sources of gut-derived 5-HT in the GI tract mucosa, of which 90\% 5-HT is synthesized in gut-resident EC cells, a subset of EE cells in the GI tract [30,31].

Trp hydroxylase (TPH), the specific serotonin-synthesizing gene, exists in two isoforms (TPH1 and TPH2) [32,33]. Both TPH1 and TPH2 show Trp hydroxylating activity. TPH1 is predominantly found in EC cells in the GI tract, whereas TPH2 is mainly expressed in the central nervous system and serotonergic neurons [34]. TPH, a rate-limiting enzyme for 5-HT production, plays a key role in the conversion of Trp to 5-hydroxytryptophan (5-HTP) [1,35]. 5-HT is rapidly converted to 5-HT by aromatic L-amino acid decarboxylase (L-AADC) in the next enzymatic step [36]. Vesicular monoamine transporter 1 (VMAT1), which participates in 5-HT storage, is expressed by granules/vesicles in EC cells [37]. Newly produced 5-HT compounded with chromogranin A (CGA), an acidic protein expressed in response to 5-HT secretion, is stored in the VMAT1 vesicles of EC cells [38] (Figure 1). 5-HT stored in the dense granules/vesicles near the basal border or apical membrane of EC cells is released into the lamina propria or lumen when EC cells are exposed to intraluminal pressure or chemical and mechanical stimulation [10,15]. The biosynthesis and metabolism of gut-derived 5-HT are illustrated in Figure 1. 


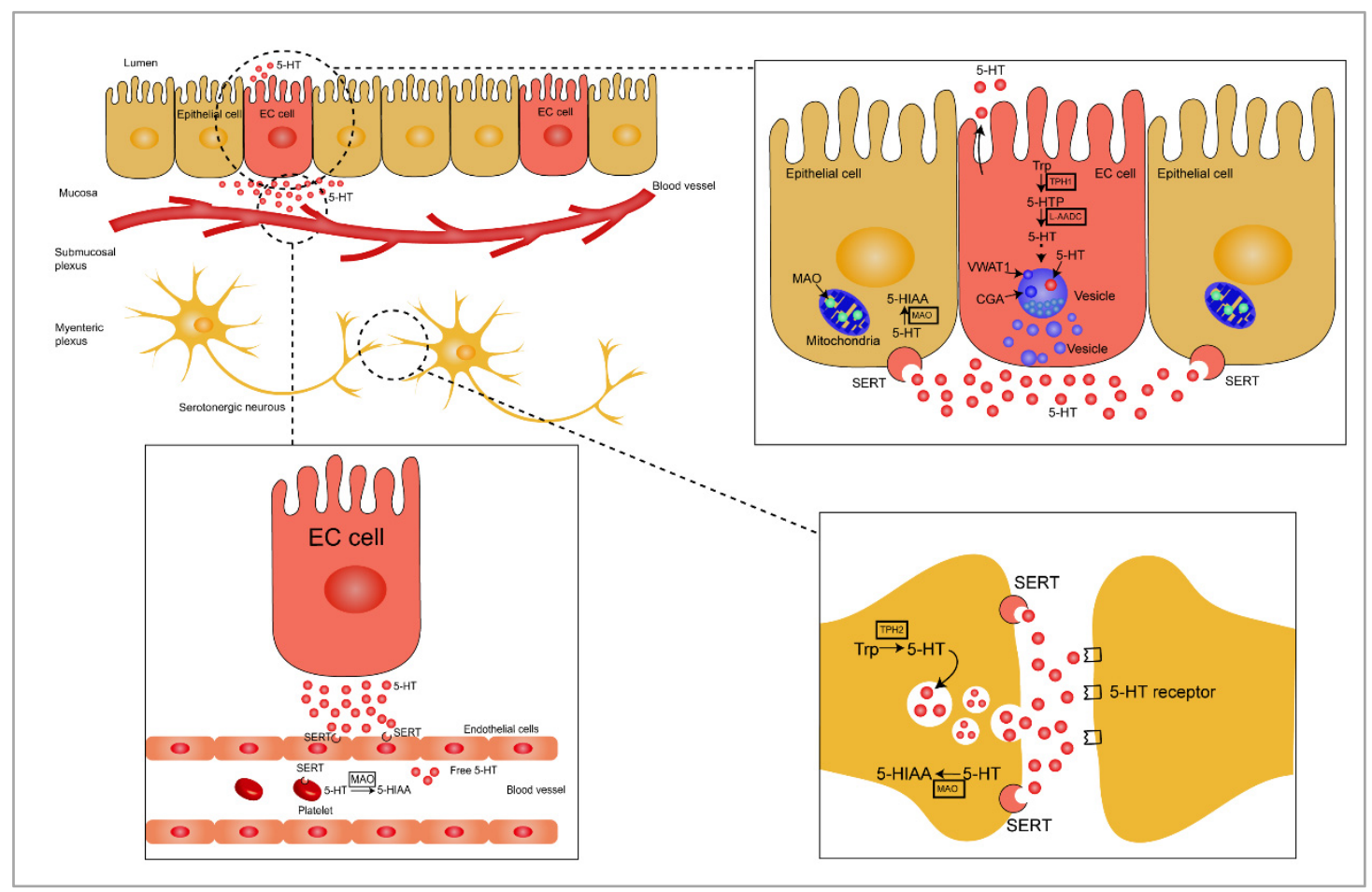

Figure 1. Schematic representation of gut-derived 5-HT biosynthesis and metabolism. Enterochromaffin (EC) cells and serotonergic neurons convert tryptophan into 5-HTP through the rate-limiting enzymes, TPH1 and TPH2, respectively, and the newly formed 5-HTP is rapidly degraded into 5-HT by L-AADC. The synthesized 5-HT and CGA are rapidly packaged into vesicles through VMAT1. EC cells express sensory receptors by acting as chemosensors to continuously release 5-HT in response to stimuli in the luminal environment, including chemical and mechanical stimulation, luminal pressure, and nutritional and intestinal microbial metabolites and hormones. Most of the 5-HT is released into the extracellular space from the bottom of EC cells, and a comparatively smaller amount of 5-HT is released into the lumen through the apical membrane. The surrounding enterocytes take up 5-HT by SERT, and 5-HT is then metabolized to 5-HIAA through MAO in the mitochondria. As a neurotransmitter, the synthetized 5-HT is packaged in synaptic vesicles in serotonergic neurons and released into the synapse cleft. Serotonin exerts a high effect on the postsynaptic membrane through the 5-HT receptors and reabsorbs on the presynaptic membrane through SERT. SERT is also detected in endothelial cells and platelets where 5-HT entering into the lamina propria is taken up and then converted into 5-HIAA or transported to peripheral target tissues. Trp, tryptophan; 5-HT, 5-hydroxytryptamine; TPH1, tryptophan hydroxylase 1; TPH2, tryptophan hydroxylase 2; 5-HTP, 5-hydroxytryptophan; 5-HIAA, 5-hydroxyindoleacetic acid; L-AADC, L-amino acid decarboxylase; CGA, chromogranin A; VMAT1, vesicular monoamine transporter 1; MAO, monoamine oxidase; SERT, serotonin reuptake transporter.

\subsection{5-HT Release and Inactivation}

In serotonergic neurons, 5-HT is packaged in synaptic vesicles and then released into synapse cleft [31]. In the gut, 5-HT is mainly released from the granules stored near the basal border of the EC cell, and small amounts of 5-HT are released into lumen through the apical membrane [35]. Once released by the EC cells, there are several possible routes that 5-HT may take. 5-HT released into the lamina propria interacts with nerve terminals, epithelial cells, and immune cells or may also be taken up into the enterocytes by SERT or may enter the general circulation [39] (Figure 1).

5 -HT is a positively charged molecule at physiological $\mathrm{pH}$, which results in the failure of transmembrane-mediated transport. SERT relies on $\mathrm{Na}^{+}$and $\mathrm{Cl}^{-}$to reuptake 5-HT released from serotonergic neurons. The driving force of the reuptake process is the transmembrane ion gradient produced by $\mathrm{Na}^{+} / \mathrm{K}^{+}$-ATPase [40,41]. In the gut, 5 -HT is also transported into surrounding enterocytes through SERT and may then be degraded into 5-hydroxyindole acetaldehyde (5-HIAL) by monoamine oxidase (MAO); 5-HIAL is, then, further transformed into 5-hydroxyindoleacetic acid (5-HIAA), which is finally excreted in 
urine [42-44]. MAO is found in the mitochondria and exists in two forms: MAO-A and MAO-B. MAO-A has a higher affinity for 5-HT [35,45,46].

5-HT released from EC cells also enter in the general circulation and are taken up by platelets via SERT. Approximately $95 \%$ of $5-\mathrm{HT}$ in the blood is stored in platelets [8] in granules together with ATP, ADP, and $\mathrm{Ca}^{2+}$ [35]. 5-HT absorbed by platelets reaches the liver through portal circulation and is transported to peripheral target tissues through bloodstream to regulate bone density [47], liver regeneration [48,49], obesity and energy metabolism [50], and allergic airway inflammation [51]. One-third of 5-HT is converted into 5-HIAA by MAO and excreted in urine, and the remaining 5-HT is degraded into 5-HTOglucuronide through glucosidase [35].

\subsection{5-HT Receptors}

5-HT acts in the lamina propria or lumen in a paracrine manner. In the intestinal epithelial cells or the mucosal afferent nerve of the lamina propria, 5-HT promotes intestinal motility, peristalsis, and secretion through binding to 5-HT-specific receptors (5-HTRs); 5-HTRs are classified into seven families according to structure, function, and effectiveness (5-HTR1-5-HTR7) [52,53]. Of note, the 5-HTR3 receptor is a ligand ion channel, and the other six receptors are G-protein-coupled receptors (GPCRs) [54]. In the gut, compelling evidence has shown that 5-HT regulates GI function by binding to different receptors (5-HTR1, 5-HTR2, 5-HTR3, 5-HTR4, and 5-HTR7). The conventional actions of 5-HT and its receptors in the GI tract are summarized in Table 1.

Table 1. Conventional effects of 5-HT and its receptors in the gastrointestinal tract.

\begin{tabular}{|c|c|c|c|}
\hline Conventional Effect & Pathway & Mediated Receptors & References \\
\hline Motility and peristaltic reflex & $\begin{array}{l}\text { Activate ascending and } \\
\text { descending interneurons }\end{array}$ & 5-HT3 and 5-HT4 receptor & {$[2,55-57]$} \\
\hline Secretion (bicarbonate and electrolyte) & $\begin{array}{l}\text { Neural mediated or through } \\
\text { paracrine pathway acts on } \\
\text { nearby enterocytes }\end{array}$ & $\begin{array}{l}\text { 5-HT2, 5-HT3 and 5-HT4 } \\
\text { receptor }\end{array}$ & {$[58,59]$} \\
\hline Pancreatic secretion and gastric emptying & $\begin{array}{l}\text { Activate vago-vagal reflex and } \\
\text { act in synergy with } \\
\text { cholecystokinin (CCK) }\end{array}$ & 5-HT2 and 5-HT3 receptor & [60-62] \\
\hline Vasodilation & $\begin{array}{l}\text { Locally regulate blood vessel } \\
\text { diameter through intrinsic } \\
\text { reflex circuits }\end{array}$ & 5-HT3 and 5-HT4 receptor & {$[2,63]$} \\
\hline Inflammation & $\begin{array}{l}\text { The pro-inflammatory actions } \\
\text { by promoting an } \\
\text { inflammatory offensive to } \\
\text { protect the gut from invasion } \\
\text { and the anti-inflammatory } \\
\text { actions by inducing } \\
\text { neurogenesis }\end{array}$ & $\begin{array}{l}\text { 5-HT1A, 2A, 2B, 2C, 5-HT3, } \\
\text { 5-HT4, and 5-HT7 receptor }\end{array}$ & {$[4-6,64-66]$} \\
\hline Neurogenesis and enteric protection & $\begin{array}{l}\text { Play an important role though } \\
\text { Neuronal 5-HT }\end{array}$ & 5-HT4 receptor & [67-69] \\
\hline Mucosal growth & $\begin{array}{l}\text { Serotonergic neurons project } \\
\text { submucosal cholinergic } \\
\text { neurons }\end{array}$ & 5-HT2A receptor & {$[70,71]$} \\
\hline
\end{tabular}

\section{5-HT in the Gut}

EC cells are considered as "sensor cells" that have the ability to sense the luminal nutrients and non-nutrient chemicals, mechanical stimulations, and signals from the gut microbiota to release 5-HT [12,35,72]. Additionally, EC cells are stimulated to trigger the release of 5-HT in response to high intraluminal pressure changes in $\mathrm{pH}$ in the gut 
lumen [73-75]. Over the past decade, many studies have demonstrated that the stimulation of the intestinal cavity by gut microbiota, nutrients, and hormones could stimulate EC cells to release 5-HT. Therefore, we have described the effect of gut microbiota, nutrients, and host-derived hormones on the secretion of 5-HT in greater details.

\subsection{Gut Microbiota and 5-HT Release}

Gut microbiota are a complex and dynamic population of microorganisms that inhabit the GI tract of humans and other mammals [76]. Over the past decade, gut microbiota have received considerable attention because of their functional role in regulating host physiology, metabolism, and immunity $[77,78]$. Emerging evidence has also shown that the gut microbiota play a critical role in regulating host 5-HT secretion in EC cells by interacting with various compounds produced by the host or gut microorganisms [76]. Short-chain fatty acids (SCFAs), as markers of bacterial metabolism [79], enhance colonic TPH1 mRNA expression by interacting with EC cells [16]. This finding is consistent with previous research that intraluminal administration of SCFAs into the proximal colon significantly augments the release and production of 5-HT by accelerating colonic transit through stimulating 5-HTR3, and thereby, promoting colonic contraction [80]. In contrast, 5-HT production following the stimulation of EC cells by SCFAs via triggering the entry of extracellular $\mathrm{Ca}^{2+}$ is unchanged [14], which indicates that the interaction between microorganisms and the host plays an indispensable role in 5-HT secretion. A study conducted by Yano et al. demonstrated that microbial-specific metabolites such as SCFAs, $\alpha$-tocopherol, tyramine, and p-aminobenzoate promote TPH1 expression and 5-HT release [81]. These results suggest an association between gut microbiota communities and host in regulating the basic biological processes through 5-HT [81]. Many different types of GPCR sensors of microbial metabolites are expressed in colonic EC cells, including olfactory receptor 558 (Olfr558), free fatty acid receptor 2 (FFAR2), olfactory receptor 78 (OLF78) that senses SCFAs, G-protein-coupled receptor 35 (GPR35) that senses small aromatic acids, G-protein-coupled bile acid receptor 1 (GPBAR1) that senses secondary bile acids, and G-protein-coupled receptor 132 (GPR132) that senses lactate and acyl amides. These receptors are activated in the process of 5-HT secretion by various gut microbial metabolites [10,13].

Most 5-HT is produced by EC cells, and a small amount of 5-HT is synthesized by a deconjugation process of glucuronide-conjugated 5-HT by a bacterial enzyme such as $\beta$-glucuronidase [12]. The gut microorganisms metabolize various substances through their interaction with the host, thereby affecting the release of 5-HT. The elucidation of the gut microbiome and host genetics in the past 10 years has helped to clarify the relationship between gut microbiota and the physiological and pathological conditions of the host. Consequently, the mechanism of microbial dependence that affects the physiological function of the host is likely to be elucidated, which would be beneficial to find methods for using gut microbial intervention to improve body health. Jonathan et al. reported that Escherichia coli Nissle 1917, one of the currently available probiotic bacteria, regulates THP1 through the interaction between host and probiotics by enhancing 5-HT level and its bioavailability in ileal tissues [42]. Because of the complexity of the gut microflora, beneficial bacteria promote body health through the 5-HT system, while pathogenic bacteria may cause intestinal diseases by damaging the intake of 5-HT. Enteropathogenic E. coli, a foodborne pathogen, inhibits SERT activity by reducing protein tyrosine phosphatase, and the damaged SERT function is associated with infectious diarrheal diseases [82]. Many studies have confirmed that the gut microbial flora and its particular metabolites influence the biosynthesis of 5-HT. However, it is largely unknown whether the alteration of 5-HT level caused by host-microbiota interaction in turn affects the colonization, growth, or adaptation of enteric microorganisms. Therefore, much work is required to investigate the metabolic pathway and molecular mechanisms of microbial metabolites in regulating 5-HT levels in the gut. 


\subsection{Nutrients and 5-HT Release}

The specialized EE cells are dispersed as single cells scattered throughout the epithelium of the GI tract from the stomach to the rectum and are considered as the largest endocrine system of the human body [83]. EE cells regulate various physiological and homeostatic functions both within and outside the gut by secreting various hormones and peptides [84]. EC cells represent around $50 \%$ of all EE cells that sense diverse dietary nutrients and metabolites to produce $~ 95 \%$ of total body 5-HT [14]. Studies conducted on human primary colonic EC cells and BON cells (immortalized cell line models of EC cells) found that 5-HT is released from EC cells in response to stimulation of luminal nutrients $[11,14,15,85]$. Unlike human primary colonic EC cells, BON cells release 5-HT following the stimulation of luminal D-glucose through sodium-glucose-linked transporter 1 (SGLT1) [86]. Additionally, the sensing of glucose in the lumen is related to the expression of SGLT3 in EC cells, which results in the release of 5-HT [87,88]. Ingested food components are digested by digestive enzymes into a form that can be absorbed into the bloodstream. Glucose is the main form of carbohydrate absorbed by mammals and serves as a luminal substance to trigger several key events in the physiological regulation of the intestinal tract [89].

As a chemosensor in the GI mucosa, EC cells release 5-HT by sensing the presence of glucose, thereby inhibiting gastric emptying and food intake by activating 5-HTR3 on exogenous afferent nerves of rodents and humans $[60,90]$. Intriguingly, the nutrient sensing capacity of EC cells in 5-HT secretion from the mouse duodenum and colon is regionspecific. Carbohydrate absorption is generally achieved over the entire small intestine, and only a small amount of glucose reaches the colon. Correspondingly, EC cells in the colon are more sensitive to glucose than those in the duodenum [14], as glucose transporter 1 (GLUT1) is highly expressed in colonic EC cells, while glucose transporter 2 (GLUT2) is abundantly expressed in duodenal EC cells [11]. The low glucose availability leads to the upregulation of GLUT1, which is a high-affinity and low-capacity glucose transporter. On the other hand, GLUT2, a low-affinity and high-capacity glucose transporter, is upregulated in a high concentration of glucose [91].

Zelkas et al. reported that 5-HT-secreting EC cells show enormous diversity in response to acute and chronic changes in glucose availability [92]. Acute exposure to high concentration of glucose results in 5-HT release from EC cells, which involves the entry of $\mathrm{Ca}^{2+}$ and an increment in the number of vesicles for exocytosis. Chronic exposure to fastingrelated levels of glucose leads to the enhancement of 5-HT synthesis through transcriptional regulation of TPH1. Consistently, food deprivation enhances gut-derived 5-HT synthesis accompanied by enhancement of lipolysis in adipocytes and liver gluconeogenesis, as well as prevention of glucose uptake in hepatocytes [93]. The enhancement of 5-HT synthesis in response to the elevated level of luminal glucose after feeding promotes gut motility and peristaltic reflex through the activation of ascending and descending interneurons to facilitate digestion. 5-HT also plays a pivotal role in enhancing body fat degradation and liver gluconeogenesis during fasting, which contributes to the maintenance of the blood glucose level.

\subsection{Hormonal Control of 5-HT Release}

The enteroendocrine system is responsible for secreting a diverse range of gut hormones, which play a highly important role in the physiological regulation of the GI tract [84]. EC cells coexist closely with other EE cells, instead of existing in "one cell type" solitarily along the length of the GI tract. A recent discovery is that EE cells communicate with EC cells locally through paracrine action in the gut [94]. The glucagon-like peptide 1 (GLP-1) receptor is particularly highly expressed in EC cells. The neighboring GLP-1-storing EE cells secrete GLP-1, and GLP-1 then stimulates EC cells to release 5-HT through the activation of GLP-1 receptors [13]. The GLP-1 receptor agonist has been reported to release 5-HT in both small intestine and colon. Of note, the spontaneous secretion of 5-HT was higher in the duodenum when compared with that in the colon. However, a significant enhancement 
in 5-HT release was detected with the treatment of a GLP-1 receptor agonist both in the duodenum and colon [13]. Moreover, it has been reported that 5-HT enhances nutrient-induced GLP-1 release from ileal segments through a process involving interactions with 5-HT receptors [95]. Using the intestinal secretin tumor cell line (STC-1) for further exploration in vitro, results revealed that 5-HT (30 or $100 \mu \mathrm{M})$ significantly enhanced GLP-1 secretion in STC-1 cells when compared with control group. Additionally, the non-specific 5-HT receptor antagonist asenapine inhibited the 5-HT-promoted GLP-1 release, which supports the 5-HT receptor-mediated mechanism [95]. Further studies are needed to investigate the interaction and mechanisms between the secretion of 5-HT and GLP-1. EC cells are also sensitive to endogenous regulatory molecules. Norepinephrine-mediated stimulation of EC cells activates alpha-2A adrenergic (Adr $\alpha 2 \mathrm{~A}$ ) receptors through catecholamines, which leads to chronic visceral hypersensitivity [10]. Hormone crosstalk exists between gut mucosal EC cells and the neighboring enterocytes within the epithelium, but its complex effects remain unknown.

\section{Physiological and Pathophysiological Role of Gut-Derived 5-HT \\ 4.1. 5-HT and Gut Inflammation}

Accumulating evidence through clinical and animal studies indicates that 5-HT, as a signaling molecule in the intestine, plays a pivotal role in intestinal inflammation (Figure 2). 5-HT signaling has been investigated in an animal model of intestinal inflammation, including 2,4,6-trinitrobenzene sulfonic acid (TNBS)-induced colitis [96] and ileitis [5,97-99], dextran sodium sulfate (DSS)-induced colitis [4,100], and trichinella spiralis infectioninduced intestinal inflammation [101]. Several studies have revealed that 5-HT is a key proinflammatory signaling molecule in gut inflammation because of the enhanced concentration of intestinal 5-HT and downregulation of SERT expression under intestinal inflammation $[6,65,102,103]$. Because of the knockout of TPH1, the concentration of 5-HT in the GI tract was significantly reduced, followed by alleviation in clinical severity and histological damage scores by pharmacological adjustment of mucosal 5-HT in DSS- or dinitrobenzene sulfonic acid (DNBS)-induced colitis [104]. Consistently, several studies have reported that a THP1 or TPH inhibitor alleviates the severity of colitis and plays a protective role in colitis $[105,106]$. Additionally, SERT transcription is reduced during intestinal inflammation, which contributes to impaired absorption of 5-HT [2,107].

5-HT plays an important role in the proinflammatory or anti-inflammatory process through binding to different receptors $[5,64]$. The anti-inflammatory role of 5-HT is accompanied by the activation of epithelial 5-HTR1A and 5-HTR4. Compared to control, the severity of experimental colitis in mice was enhanced through intraluminal administration of a 5-HTR1A and 5-HTR4 antagonist [4,64]. Upregulation of 5-HTR4 expression protects the large intestine from DSS- or TNBS-induced colitis by maintaining epithelial integrity, stimulating the proliferation of crypt epithelial cells, and reducing apoptosis [64]. A study reported that treatment with a 5-HTR2A antagonist (Ketanserin) alleviates intestinal inflammation by improving gut integrity, reducing the production of inflammatory cytokines in macrophages, and inhibiting the activation of nuclear factor- $\kappa \mathrm{B}(\mathrm{NF}-\kappa \mathrm{B})$ in experimental colitis; this result further confirmed the deleterious role of 5-HTR2A on intestinal inflammation [108]. However, the 5-HT receptors involved in the proinflammatory and anti-inflammatory processes reported in the current literature are contradictory. Spohn et al. demonstrated that chemical activation of 5-HTR4 reduced the severity of TNBS- and DSS-induced colitis [64]. In contrast, Rapalli et al. found that the inhibition of 5-HTR4 improves the progression and pathological outcome of TNBS-induced colitis, thus suggesting the detrimental effect of 5-HTR4 on TNBS-induced colitis [5]. Kim et al. also reported that the inhibition of 5-HTR7 signaling reversed acute and chronic colitis induced by DSS or TNBS [109]. In contrast, several research studies have demonstrated that the development of colitis was not affected by 5-HTR7 [4,5]. Thus, further studies are required to determine the role of 5-HT receptors on experimental colitis to reveal the association 
between 5-HT receptors and the downstream signaling pathways under inflammatory conditions (Figure 2).

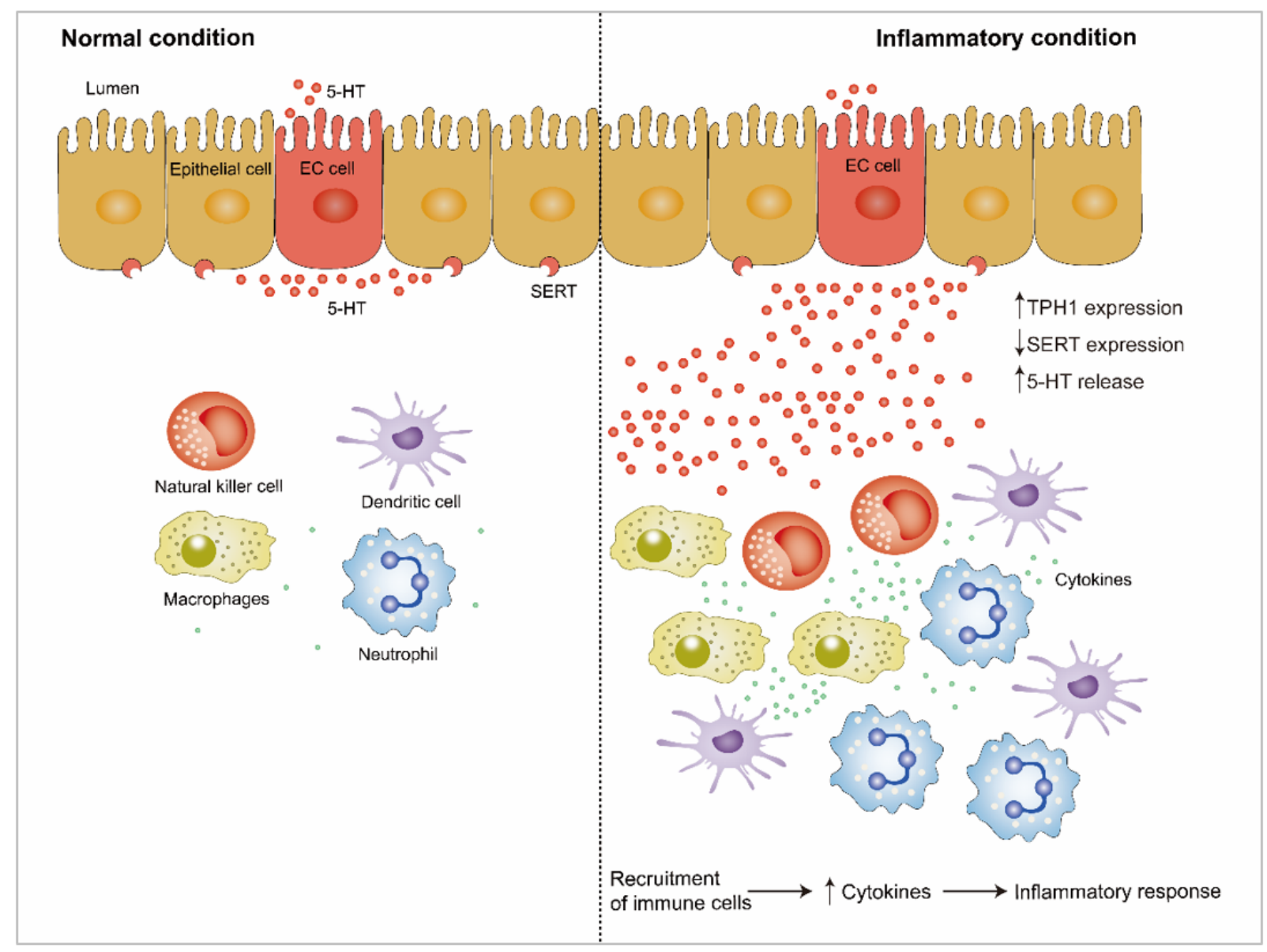

Figure 2. The role of gut-derived 5-HT under inflammatory condition and inflammatory condition. THP1 and SERT expression, as well as 5-HT release can be altered under inflammatory condition. Enhanced 5-HT promotes recruitment of immune cells, such as natural killer cells, dendritic cell, macrophages, and neutrophil during inflammation. Subsequently, enhanced cytokines production is released from immune cells, which can promote inflammatory response. Upwards pointing arrows indicate an enhancement, and downwards pointing arrows indicate a decrease. 5-HT, 5-hydroxytryptamine; TPH1, tryptophan hydroxylase 1; SERT, serotonin reuptake transporter.

The immune response to inflammation involves the extensive proliferation of immune cells and aberrant production of immune mediators and cytokines such as tumor necrosis factor (TNF)- $\alpha$, interferon (IFN)- $\gamma$, interleukin (IL)- $1 \beta$, IL-6, and IL-8 and their related signaling pathways $[110,111]$. 5-HT receptors have been identified in human and rodent immune cells [44]. EC cells are in close proximity with immune cells in the gut mucosa, suggesting the existence of interaction between EC cells and immune cells [112]. Immune cells, including dendritic cells, macrophages, neutrophils, lymphocytes, and B lymphocytes, proliferate in the 5-HT-mediated proinflammatory response [4,113], suggesting that 5-HT plays a vital part in the immune response. Recent studies have shown that 5-HT signaling is altered by proinflammatory cytokines such as TNF- $\alpha$, IL- $1 \beta$, IL-6, and IFN- $\gamma$, as well as the anti-inflammatory cytokine IL-10 by regulating the expression and function of SERT. Intriguingly, several studies have found that IFN- $\gamma$, TNF- $\alpha$, and IL- 6 and a low concentration of IL-10 caused a significant decrease in the function and activity of epithelial SERT $[4,114-116]$. 


\subsection{5-HT and Liver Regeneration}

5-HT acting on the liver is entirely derived from the gut because of the lack of 5HT synthesis capacity in hepatocytes [117]. 5-HT activated in platelets is released in the liver and mediates liver regeneration after partial hepatectomy and inhibits liver regeneration in the TPH1 gene knockout mice [48,49]. Liver regeneration was mediated by promoting DNA synthesis and cell proliferation through acting on 5-HTR2 [118] and 5-HTR7 [119,120]. Another study revealed that SERT knockout in platelets has no effect on liver regeneration, thus indicating that the extremely low level of 5-HT in plasma is sufficient for liver regeneration [121].

\subsection{5-HT and Energy Homeostasis}

Metabolic homeostasis is regulated by nerves and hormones. Several recent studies have shown that 5-HT, an important endocrine substance and hormone, regulates the metabolic function of many tissues and influences obesity and energy metabolism [1,50,122,123]. The liver, a pivotal organ in an organism's metabolism, plays a central role in regulating plasma glucose metabolism and energy metabolism [124]. 5-HT cannot be produced by hepatocytes; hence, all the peripheral 5-HT in the liver is derived from the gut. A previous study revealed that 5-HT produced during fasting promotes gluconeogenesis by enhancing the activity of two key gluconeogenesis rate-limiting enzymes (glucose 6phosphatase and fructose 1,6-bisphosphatase) through 5-HTR2B [93]. The cyclic AMP that is the downstream of 5-HTR2B is enhanced at transcriptional level after the elevated activity of two key enzymes; subsequently, cAMP-dependent protein kinase A (PKA) and CREB are activated [125]. Additionally, gut-derived 5-HT in hepatocytes prevents glucose uptake in a GLUT2-dependent manner, thereby further favoring the maintenance of blood glucose levels [93]. Because TPH1 is expressed in adipocytes, the regulation of 5-HT in adipose tissue is more complicated than that in the liver. TPH1-produced 5-HT in adipocytes regulates the metabolism of adipose tissue through local autocrine signals $[50,126,127]$. In white adipocytes, 5-HT synthesized in EC cells enhances the phosphorylation and activity of hormone-sensitive lipase (HSL) through binding to the 5-HT2B receptor, therefore elevating circulatory free fatty acids and glycerol [93]. There are two possible pathways to promote lipolysis and inhibit lipogenesis: (1) HSL is activated indirectly by cAMP and cAMP-dependent protein kinase A (PKA); (2) perilipin is phosphorylated by PKA and, consequently, stimulates phosphorylation of HSL [128]. Enhanced glycerol acts as a fuel of gluconeogenesis and is converted into acetyl-CoA by $\beta$-oxidation for the synthesis of ketone bodies [1]. Because of the complexity of the serotonergic system in adipose tissue, more studies are required to elucidate the underlying responsible role for 5- $\mathrm{HT}$ in the future.

\subsection{5-HT and Bone Remodeling}

5-HT and its role in bone metabolism are receiving great interest from researchers. Bone remodeling and renewal is a highly integrated process, which includes bone resorption through osteoclasts and bone formation through osteoblasts. These two processes are dynamically balanced, which contributes to the maintenance of bone [129]. Lowdensity lipoprotein receptor-related protein-5 (Lrp5) is essential for Wnt signaling to form bones [130-132]. Previous studies have reported that Lrp5 is expressed in osteoblasts and EC cells in the GI tract [133]. However, Lrp5 could act in EC cells in the gut, not in osteoblast, to regulate bone-mass accrual via a Wnt-independent pathway [134]. Lrp5 inhibits the expression of TPH1, thereby reducing 5-HT concentration in the blood. Less 5-HT binds to 5-HTR1B in osteoblasts and 5-HTR1B signaling is reduced in osteoblasts. As a result, the expression and function of cyclic AMP response element binding protein (CREB) is enhanced, which promotes cyclin expression and results in enhanced osteoblasts differentiation and proliferation [134]. In this process, 5-HT derived from the GI tract and transported through the circulation is detrimental to bone formation through inhibiting osteoblast proliferation [134] (Figure 3). Consistently, some studies have supported that 
gut-derived 5-HT could suppress bone growth in rats $[135,136]$. Thus, pharmacological inhibition of gut-derived 5-HT synthesis through the inhibitor of THP1 may be a potential bone anabolic treatment for low bone mass $[137,138]$. Additionally, there are conflicting results in the model where Lrp5 regulates bone mass through duodenal 5-HT. A study conducted by Cui et al. demonstrated that gut-derived 5-HT synthesis is not associated with Lrp5 [131]. Growing evidence has shown that 5-HT plays an important role in bone metabolism. However, because of the different synthesis sites of 5-HT, including brainderived 5-HT [139], gut-derived 5-HT [134,137,140], and bone-derived 5-HT [141], 5-HT has different roles in bone metabolism (Figure 3).

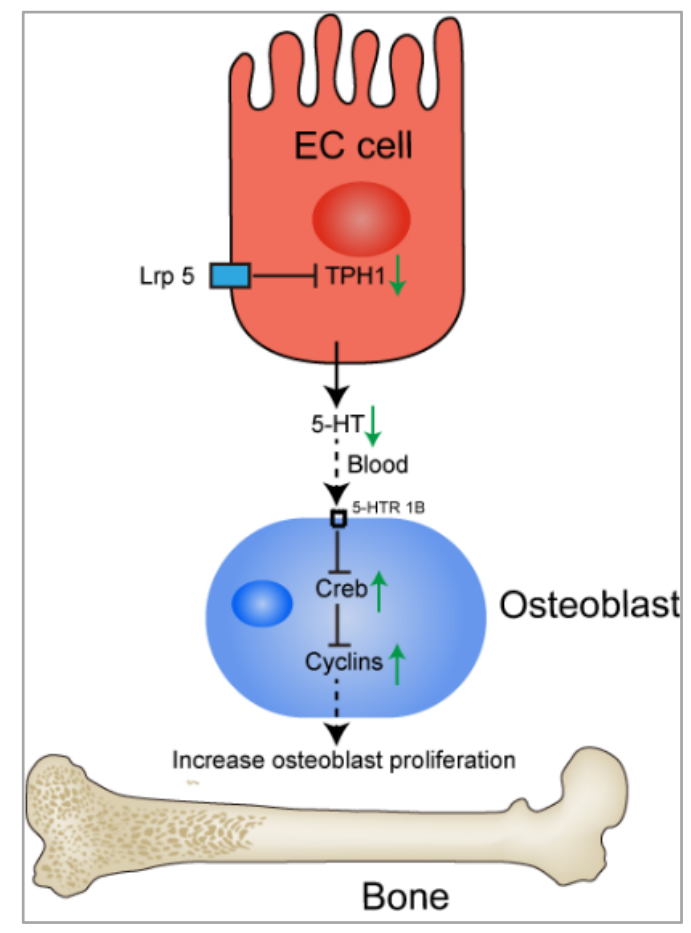

Figure 3. The action of Lrp5 and 5-HT on the regulation of bone formation. Lrp5 inhibits the expression of TPH1 in cells. As a result, reduced 5-HT concentration in circulation reduces 5HTR1B signaling in osteoblasts. Cyclic AMP response element binding protein (CREB) and cyclin expression is enhanced, which favors osteoblasts proliferation and bone formation. Lrp5, low-density lipoprotein receptor-related protein-5; 5-HT, 5-hydroxytryptamine; CREB, cyclic AMP response element binding protein.

\section{Conclusions}

5-HT synthesized in EC cells has been recognized for decades as an important signaling molecule in the gut. It is well known that 5-HT derived from neurons and EC cells is involved in the regulation of GI peristalsis, sensation, and secretion. Approximately $95 \%$ of 5-HT in the body is synthesized and secreted by EC cells in the GI tract. The findings of several studies have suggested that gut microbiota, nutrients, and hormones could stimulate EC cells to release 5-HT. New clues from recent studies expand our understanding of the functional role of gut-derived 5-HT in and far beyond the gut. As an important neurotransmitter and hormone in the GI tract, research on 5-HT is increasing, but the underlying mechanisms of the relationship between 5-HT and physiological actions in the body remain largely unclear. Therefore, it is essential to highlight the functional role of 5-HT and various factors (gut microbiota, nutrients, and hormones) in the regulation of 5-HT secretion in order to facilitate the application for 5-HT in nutrition, clinical medicine, and health. 
Author Contributions: Writing-review and editing, N.L., S.S., P.W., Y.S. and Q.H.; supervision, X.W. All authors have read and agreed to the published version of the manuscript.

Funding: This study was supported by the National Natural Science Foundation of China (No. 32000082, 32001676), and State Key Laboratory of Animal Nutrition (2004DA125184F1909).

Institutional Review Board Statement: Not applicable.

Informed Consent Statement: Not applicable.

Data Availability Statement: Not applicable.

Conflicts of Interest: The authors declare no conflict of interest.

\begin{abstract}
Abbreviations
5-HIAA, 5-hydroxy indole acetic acid; 5-HIAL, 5-hydroxyindole acetaldehyde; 5-HT, 5hydroxytryptamine; 5-HTP, 5-hydroxytryptophan; 5-HTR, 5-HT receptor; AAs, amino acids; Adr $\alpha 2 \mathrm{~A}$, alpha-2A adrenergic receptor; CGA, chromogranin A; MAO, monoamine oxidase; DNBS, dinitrobenzene sulfonic acid; DSS, dextran sodium sulfate; EC, enterochromaffin; EE, enteroendocrine; FFAR2, free fatty acid receptor; GI, gastrointestinal; GLP-1, glucagon-like peptide 1; GLUT1, glucose transporter 1; GLUT2, glucose transporter 2; GPBAR1, G-protein-coupled bile acid receptor 1; GPCRs, G-protein-coupled receptors; GPR132, G-protein-coupled receptors 132; GPR35, G-protein-coupled receptors 35; HSL, hormone-sensitive lipase; IBD, inflammatory bowel disease; IFN, interferon; IL, interleukin; L-AADC, L-amino acid decarboxylase; Lrp5, low-density lipoprotein receptor-related protein-5; NF-кB, nuclear factor-kB; Olf558, olfactory receptor 558; OLF78, olfactory receptor 78; SCFAs, short-chain fatty acids; SERT, serotonin reuptake transporter; SGLT1, sodium-glucose-linked transporter 1; SGLT3, sodium-glucose-linked transporter 3; TPH 1, tryptophan hydroxylase 1; THP2, tryptophan hydroxylase 2; TNBS, 2,4,6-trinitrobenzene sulfonic acid; TNF, tumor necrosis factor; Trp, tryptophan; VMAT1, vesicular monoamine transporter1.
\end{abstract}

\title{
References
}

1. Martin, A.M.; Young, R.L.; Leong, L.; Rogers, G.B.; Spencer, N.J.; Jessup, C.F.; Keating, D.J. The diverse metabolic roles of peripheral serotonin. Endocrinology 2017, 158, 1049-1063. [CrossRef]

2. Mawe, G.M.; Hoffman, J.M. Serotonin signalling in the gut-functions, dysfunctions and therapeutic targets. Nat. Rev. Gastroenterol. Hepatol. 2013, 10, 473-486. [CrossRef]

3. Spohn, S.N.; Mawe, G.M. Non-conventional features of peripheral serotonin signalling-The gut and beyond. Nat. Rev. Gastroenterol. Hepatol. 2017, 14, 412-420. [CrossRef]

4. Wang, B.; Sun, S.; Liu, M.; Chen, H.; Liu, N.; Wu, Z.; Wu, G.; Dai, Z. Dietary L-tryptophan regulates colonic serotonin homeostasis in mice with dextran sodium sulfate-induced colitis. J. Nutr. 2020, 150, 1966-1976. [CrossRef] [PubMed]

5. Rapalli, A.; Bertoni, S.; Arcaro, V.; Saccani, F.; Grandi, A.; Vivo, V.; Cantoni, A.M.; Barocelli, E. Dual role of endogenous serotonin in 2,4,6-trinitrobenzene sulfonic acid-induced colitis. Front. Pharmacol. 2016, 7, 68. [CrossRef]

6. MacEachern, S.J.; Keenan, C.M.; Papakonstantinou, E.; Sharkey, K.A.; Patel, B.A. Alterations in melatonin and 5-HT signalling in the colonic mucosa of mice with dextran-sodium sulfate-induced colitis. Br. J. Pharmacol. 2018, 175, 1535-1547. [CrossRef]

7. Coates, M.D.; Tekin, I.; Vrana, K.E.; Mawe, G.M. Review article: The many potential roles of intestinal serotonin (5hydroxytryptamine, 5-HT) signalling in inflammatory bowel disease. Aliment. Pharmacol. Ther. 2017, 46, 569-580. [CrossRef]

8. Terry, N.; Margolis, K.G. Serotonergic Mechanisms Regulating the GI Tract: Experimental Evidence and Therapeutic Relevance. Handb. Exp. Pharmacol. 2017, 239, 319-342. [CrossRef]

9. Wang, F.; Knutson, K.; Alcaino, C.; Linden, D.R.; Gibbons, S.J.; Kashyap, P.; Grover, M.; Oeckler, R.; Gottlieb, P.A.; Li, H.J.; et al. Mechanosensitive ion channel Piezo2 is important for enterochromaffin cell response to mechanical forces. J. Physiol. 2017, 595, 79-91. [CrossRef]

10. Bellono, N.W.; Bayrer, J.R.; Leitch, D.B.; Castro, J.; Zhang, C.; O’Donnell, T.A.; Brierley, S.M.; Ingraham, H.A.; Julius, D. Enterochromaffin cells are gut chemosensors that couple to sensory neural pathways. Cell 2017, 170, 185-198.e116. [CrossRef]

11. Martin, A.M.; Lumsden, A.L.; Young, R.L.; Jessup, C.F.; Spencer, N.J.; Keating, D.J. The nutrient-sensing repertoires of mouse enterochromaffin cells differ between duodenum and colon. Neurogastroenterol. Motil. 2017, 29. [CrossRef] [PubMed]

12. Hata, T.; Asano, Y.; Yoshihara, K.; Kimura-Todani, T.; Miyata, N.; Zhang, X.T.; Takakura, S.; Aiba, Y.; Koga, Y.; Sudo, N. Regulation of gut luminal serotonin by commensal microbiota in mice. PLoS ONE 2017, 12, e0180745. [CrossRef] [PubMed]

13. Lund, M.L.; Egerod, K.L.; Engelstoft, M.S.; Dmytriyeva, O.; Theodorsson, E.; Patel, B.A.; Schwartz, T.W. Enterochromaffin 5-HT cells-A major target for GLP-1 and gut microbial metabolites. Mol. Metab. 2018, 11, 70-83. [CrossRef] 
14. Martin, A.M.; Lumsden, A.L.; Young, R.L.; Jessup, C.F.; Spencer, N.J.; Keating, D.J. Regional differences in nutrient-induced secretion of gut serotonin. Physiol. Rep. 2017, 5. [CrossRef] [PubMed]

15. Braun, T.; Voland, P.; Kunz, L.; Prinz, C.; Gratzl, M. Enterochromaffin cells of the human gut: Sensors for spices and odorants. Gastroenterology 2007, 132, 1890-1901. [CrossRef]

16. Reigstad, C.S.; Salmonson, C.E.; Rainey, J.F., 3rd; Szurszewski, J.H.; Linden, D.R.; Sonnenburg, J.L.; Farrugia, G.; Kashyap, P.C. Gut microbes promote colonic serotonin production through an effect of short-chain fatty acids on enterochromaffin cells. Faseb. J. 2015, 29, 1395-1403. [CrossRef] [PubMed]

17. Hou, Y.; Wu, G. Nutritionally essential amino acids. Adv. Nutr. 2018, 9, 849-851. [CrossRef]

18. Lopez, M.J.; Mohiuddin, S.S. Biochemistry, essential amino acids. In StatPearls; StatPearls Publishing LLC.: Treasure Island, FL, USA, 2021.

19. Comai, S.; Bertazzo, A.; Brughera, M.; Crotti, S. Tryptophan in health and disease. Adv. Clin. Chem. 2020, 95, 165-218. [CrossRef]

20. Roth, W.; Zadeh, K.; Vekariya, R.; Ge, Y.; Mohamadzadeh, M. Tryptophan metabolism and gut-brain homeostasis. Int. J. Mol. Sci. 2021, 22, 2973. [CrossRef] [PubMed]

21. Vivi, D.D.; Bentley, G.E. Seasonal reproduction in vertebrates: Melatonin synthesis, binding, and functionality using tinbergen's four questions. Molecules 2018, 23, 652. [CrossRef]

22. Wu, G.; Song, D.; Wei, Q.; Xing, J.; Shi, X.; Shi, F. Melatonin mitigates bisphenol A-induced estradiol production and proliferation by porcine ovarian granulosa cells in vitro. Anim. Reprod. Sci. 2018, 192, 91-98. [CrossRef] [PubMed]

23. Rode, J.; Yang, L.; König, J.; Hutchinson, A.N.; Wall, R.; Venizelos, N.; Brummer, R.J.; Rangel, I.; Vumma, R. Butyrate rescues oxidative stress-induced transport deficits of tryptophan: Potential implication in affective or gut-brain axis disorders. Neuropsychobiology 2020, 1-11. [CrossRef]

24. Gao, J.; Xu, K.; Liu, H.; Liu, G.; Bai, M.; Peng, C.; Li, T.; Yin, Y. Impact of the gut microbiota on intestinal immunity mediated by tryptophan metabolism. Front. Cell Infect. Microbiol. 2018, 8, 13. [CrossRef]

25. Badawy, A.A. Kynurenine pathway of tryptophan metabolism: Regulatory and functional aspects. Int. J. Tryptophan Res. 2017, 10, 1178646917691938. [CrossRef]

26. Dehhaghi, M.; Kazemi Shariat Panahi, H.; Guillemin, G.J. Microorganisms, tryptophan metabolism, and kynurenine pathway: A complex interconnected loop influencing human health status. Int. J. Tryptophan Res. 2019, 12, 1178646919852996. [CrossRef] [PubMed]

27. Agus, A.; Planchais, J.; Sokol, H. Gut microbiota regulation of tryptophan metabolism in health and disease. Cell Host Microbe 2018, 23, 716-724. [CrossRef] [PubMed]

28. Badawy, A.A. Tryptophan availability for kynurenine pathway metabolism across the life span: Control mechanisms and focus on aging, exercise, diet and nutritional supplements. Neuropharmacology 2017, 112, 248-263. [CrossRef] [PubMed]

29. Jones, L.A.; Sun, E.W.; Martin, A.M.; Keating, D.J. The ever-changing roles of serotonin. Int. J. Biochem. Cell Biol. 2020, 125, 105776. [CrossRef] [PubMed]

30. Shajib, M.S.; Baranov, A.; Khan, W.I. Diverse effects of gut-derived serotonin in intestinal inflammation. ACS Chem. Neurosci. 2017, 8, 920-931. [CrossRef]

31. Yabut, J.M.; Crane, J.D.; Green, A.E.; Keating, D.J.; Khan, W.I.; Steinberg, G.R. Emerging roles for serotonin in regulating metabolism: New implications for an ancient molecule. Endocr. Rev. 2019, 40, 1092-1107. [CrossRef]

32. Walther, D.J.; Peter, J.U.; Bashammakh, S.; Hörtnagl, H.; Voits, M.; Fink, H.; Bader, M. Synthesis of serotonin by a second tryptophan hydroxylase isoform. Science 2003, 299, 76. [CrossRef]

33. Park, S.; Kim, Y.; Lee, J.; Lee, J.Y.; Kim, H.; Lee, S.; Oh, C.M. A systems biology approach to investigating the interaction between serotonin synthesis by tryptophan hydroxylase and the metabolic homeostasis. Int. J. Mol. Sci. 2021, 22, 2452. [CrossRef] [PubMed]

34. Swami, T.; Weber, H.C. Updates on the biology of serotonin and tryptophan hydroxylase. Curr. Opin. Endocrinol. Diabetes Obes. 2018, 25, 12-21. [CrossRef] [PubMed]

35. Bertrand, P.P.; Bertrand, R.L. Serotonin release and uptake in the gastrointestinal tract. Auton. Neurosci. 2010, 153, 47-57. [CrossRef]

36. Penuelas, A.; Tashima, K.; Tsuchiya, S.; Matsumoto, K.; Nakamura, T.; Horie, S.; Yano, S. Contractile effect of TRPA1 receptor agonists in the isolated mouse intestine. Eur. J. Pharmacol. 2007, 576, 143-150. [CrossRef]

37. Rindi, G.; Leiter, A.B.; Kopin, A.S.; Bordi, C.; Solcia, E. The "normal" endocrine cell of the gut: Changing concepts and new evidences. Ann. N. Y. Acad. Sci. 2004, 1014, 1-12. [CrossRef]

38. Montesinos, M.S.; Machado, J.D.; Camacho, M.; Diaz, J.; Morales, Y.G.; Alvarez de la Rosa, D.; Carmona, E.; Castañeyra, A.; Viveros, O.H.; O'Connor, D.T.; et al. The crucial role of chromogranins in storage and exocytosis revealed using chromaffin cells from chromogranin A null mouse. J. Neurosci. 2008, 28, 3350-3358. [CrossRef]

39. O'Hara, J.R.; Sharkey, K.A. Proliferative capacity of enterochromaffin cells in guinea-pigs with experimental ileitis. Cell Tissue Res. 2007, 329, 433-441. [CrossRef]

40. El Aidy, S.; Ramsteijn, A.S.; Dini-Andreote, F.; van Eijk, R.; Houwing, D.J.; Salles, J.F.; Olivier, J.D.A. Serotonin transporter genotype modulates the gut microbiota composition in young rats, an effect augmented by early life stress. Front. Cell Neurosci. 2017, 11, 222. [CrossRef]

41. Gill, R.K.; Pant, N.; Saksena, S.; Singla, A.; Nazir, T.M.; Vohwinkel, L.; Turner, J.R.; Goldstein, J.; Alrefai, W.A.; Dudeja, P.K. Function, expression, and characterization of the serotonin transporter in the native human intestine. Am. J. Physiol. Gastrointest Liver Physiol. 2008, 294, G254-G262. [CrossRef] 
42. Nzakizwanayo, J.; Dedi, C.; Standen, G.; Macfarlane, W.M.; Patel, B.A.; Jones, B.V. Escherichia coli Nissle 1917 enhances bioavailability of serotonin in gut tissues through modulation of synthesis and clearance. Sci. Rep. 2015, 5, 17324. [CrossRef]

43. Saraf, M.K.; Piccolo, B.D.; Bowlin, A.K.; Mercer, K.E.; LeRoith, T.; Chintapalli, S.V.; Shankar, K.; Badger, T.M.; Yeruva, L. Formula diet driven microbiota shifts tryptophan metabolism from serotonin to tryptamine in neonatal porcine colon. Microbiome 2017, 5, 77. [CrossRef] [PubMed]

44. Shajib, M.S.; Khan, W.I. The role of serotonin and its receptors in activation of immune responses and inflammation. Acta Physiol. 2015, 213, 561-574. [CrossRef] [PubMed]

45. Keszthelyi, D.; Troost, F.J.; Masclee, A.A. Understanding the role of tryptophan and serotonin metabolism in gastrointestinal function. Neurogastroenterol. Motil. 2009, 21, 1239-1249. [CrossRef]

46. Edmondson, D.E.; Binda, C. Monoamine oxidases. Subcell Biochem. 2018, 87, 117-139. [CrossRef] [PubMed]

47. Lavoie, B.; Lian, J.B.; Mawe, G.M. Regulation of bone metabolism by serotonin. Adv. Exp. Med. Biol. 2017, 1033, 35-46. [CrossRef]

48. Lesurtel, M.; Graf, R.; Aleil, B.; Walther, D.J.; Tian, Y.; Jochum, W.; Gachet, C.; Bader, M.; Clavien, P.A. Platelet-derived serotonin mediates liver regeneration. Science 2006, 312, 104-107. [CrossRef] [PubMed]

49. Fang, Y.; Liu, C.; Shu, B.; Zhai, M.; Deng, C.; He, C.; Luo, M.; Han, T.; Zheng, W.; Zhang, J.; et al. Axis of serotonin -pERK-YAP in liver regeneration. Life Sci. 2018, 209, 490-497. [CrossRef] [PubMed]

50. Wyler, S.C.; Lord, C.C.; Lee, S.; Elmquist, J.K.; Liu, C. Serotonergic control of metabolic homeostasis. Front. Cell Neurosci. 2017, 11, 277. [CrossRef]

51. Flanagan, T.W.; Sebastian, M.N.; Battaglia, D.M.; Foster, T.P.; Cormier, S.A.; Nichols, C.D. 5-HT(2) receptor activation alleviates airway inflammation and structural remodeling in a chronic mouse asthma model. Life Sci. 2019, 236, 116790. [CrossRef]

52. Hannon, J.; Hoyer, D. Molecular biology of 5-HT receptors. Behav. Brain. Res. 2008, 195, 198-213. [CrossRef]

53. Pytliak, M.; Vargová, V.; Mechírová, V.; Felšöci, M. Serotonin receptors-From molecular biology to clinical applications. Physiol. Res. 2011, 60, 15-25. [CrossRef]

54. Hoyer, D.; Hannon, J.P.; Martin, G.R. Molecular, pharmacological and functional diversity of 5-HT receptors. Pharmacol. Biochem. Behav. 2002, 71, 533-554. [CrossRef]

55. Margolis, K.G.; Li, Z.; Stevanovic, K.; Saurman, V.; Israelyan, N.; Anderson, G.M.; Snyder, I.; Veenstra-VanderWeele, J.; Blakely, R.D.; Gershon, M.D. Serotonin transporter variant drives preventable gastrointestinal abnormalities in development and function. J. Clin. Investig. 2016, 126, 2221-2235. [CrossRef] [PubMed]

56. Kendig, D.M.; Grider, J.R. Serotonin and colonic motility. Neurogastroenterol. Motil. 2015, 27, 899-905. [CrossRef]

57. Keating, D.J.; Spencer, N.J. What is the role of endogenous gut serotonin in the control of gastrointestinal motility? Pharmacol. Res. 2019, 140, 50-55. [CrossRef]

58. Tuo, B.G.; Isenberg, J.I. Effect of 5-hydroxytryptamine on duodenal mucosal bicarbonate secretion in mice. Gastroenterology 2003, 125, 805-814. [CrossRef]

59. Tuo, B.G.; Sellers, Z.; Paulus, P.; Barrett, K.E.; Isenberg, J.I. 5-HT induces duodenal mucosal bicarbonate secretion via cAMPand Ca2+-dependent signaling pathways and 5-HT4 receptors in mice. Am. J. Physiol. Gastrointest. Liver Physiol. 2004, 286, G444-G451. [CrossRef]

60. Raybould, H.E.; Glatzle, J.; Robin, C.; Meyer, J.H.; Phan, T.; Wong, H.; Sternini, C. Expression of 5-HT3 receptors by extrinsic duodenal afferents contribute to intestinal inhibition of gastric emptying. Am. J. Physiol. Gastrointest. Liver Physiol. 2003, 284, G367-G372. [CrossRef]

61. Browning, K.N. Role of central vagal 5-HT3 receptors in gastrointestinal physiology and pathophysiology. Front. Neurosci. 2015, 9, 413. [CrossRef]

62. Li, Y.; Hao, Y.; Zhu, J.; Owyang, C. Serotonin released from intestinal enterochromaffin cells mediates luminal non-cholecystokininstimulated pancreatic secretion in rats. Gastroenterology 2000, 118, 1197-1207. [CrossRef]

63. Vanner, S.; Macnaughton, W.K. Submucosal secretomotor and vasodilator reflexes. Neurogastroenterol. Motil. 2004, 16 (Suppl. 1), 39-43. [CrossRef]

64. Spohn, S.N.; Bianco, F.; Scott, R.B.; Keenan, C.M.; Linton, A.A.; O’Neill, C.H.; Bonora, E.; Dicay, M.; Lavoie, B.; Wilcox, R.L.; et al. Protective actions of epithelial 5-Hydroxytryptamine 4 receptors in normal and inflamed colon. Gastroenterology 2016, 151, 933-944.e933. [CrossRef] [PubMed]

65. Tada, Y.; Ishihara, S.; Kawashima, K.; Fukuba, N.; Sonoyama, H.; Kusunoki, R.; Oka, A.; Mishima, Y.; Oshima, N.; Moriyama, I.; et al. Downregulation of serotonin reuptake transporter gene expression in healing colonic mucosa in presence of remaining low-grade inflammation in ulcerative colitis. J. Gastroenterol. Hepatol. 2016, 31, 1443-1452. [CrossRef]

66. Iacomino, G.; Rotondi Aufiero, V.; Iannaccone, N.; Melina, R.; Giardullo, N.; De Chiara, G.; Venezia, A.; Taccone, F.S.; Iaquinto, G.; Mazzarella, G. IBD: Role of intestinal compartments in the mucosal immune response. Immunobiology 2020, 225, 151849. [CrossRef]

67. Fiorica-Howells, E.; Maroteaux, L.; Gershon, M.D. Serotonin and the 5-HT(2B) receptor in the development of enteric neurons. J. Neurosci. 2000, 20, 294-305. [CrossRef]

68. Liu, M.T.; Kuan, Y.H.; Wang, J.; Hen, R.; Gershon, M.D. 5-HT4 receptor-mediated neuroprotection and neurogenesis in the enteric nervous system of adult mice. J. Neurosci. 2009, 29, 9683-9699. [CrossRef] 
69. Matsuyoshi, H.; Kuniyasu, H.; Okumura, M.; Misawa, H.; Katsui, R.; Zhang, G.X.; Obata, K.; Takaki, M. A 5-HT(4)-receptor activation-induced neural plasticity enhances in vivo reconstructs of enteric nerve circuit insult. Neurogastroenterol. Motil. 2010, 22, 806-813.e226. [CrossRef]

70. Gross, E.R.; Gershon, M.D.; Margolis, K.G.; Gertsberg, Z.V.; Li, Z.; Cowles, R.A. Neuronal serotonin regulates growth of the intestinal mucosa in mice. Gastroenterology 2012, 143, 408-417.e402. [CrossRef]

71. Tackett, J.J.; Gandotra, N.; Bamdad, M.C.; Muise, E.D.; Cowles, R.A. Enhanced serotonin signaling stimulates ordered intestinal mucosal growth. J. Surg. Res. 2017, 208, 198-203. [CrossRef]

72. Nozawa, K.; Kawabata-Shoda, E.; Doihara, H.; Kojima, R.; Okada, H.; Mochizuki, S.; Sano, Y.; Inamura, K.; Matsushime, H.; Koizumi, T.; et al. TRPA1 regulates gastrointestinal motility through serotonin release from enterochromaffin cells. Proc. Natl. Acad. Sci. USA 2009, 106, 3408-3413. [CrossRef]

73. Fujimiya, M.; Okumiya, K.; Kuwahara, A. Immunoelectron microscopic study of the luminal release of serotonin from rat enterochromaffin cells induced by high intraluminal pressure. Histochem. Cell Biol. 1997, 108, 105-113. [CrossRef]

74. Bulbring, E.; Lin, R.C. The effect of intraluminal application of 5-hydroxytryptamine and 5-hydroxytryptophan on peristalsis; the local production of 5-HT and its release in relation to intraluminal pressure and propulsive activity. J. Physiol. 1958, 140, 381-407.

75. Gershon, M.D. Review article: Serotonin receptors and transporters-Roles in normal and abnormal gastrointestinal motility. Aliment. Pharmacol. Ther. 2004, 20 (Suppl. 7), 3-14. [CrossRef]

76. Thursby, E.; Juge, N. Introduction to the human gut microbiota. Biochem. J. 2017, 474, 1823-1836. [CrossRef]

77. Lavelle, A.; Sokol, H. Gut microbiota-derived metabolites as key actors in inflammatory bowel disease. Nat. Rev. Gastroenterol. Hepatol. 2020, 17, 223-237. [CrossRef]

78. Mentella, M.C.; Scaldaferri, F.; Pizzoferrato, M.; Gasbarrini, A.; Miggiano, G.A.D. Nutrition, IBD and gut microbiota: A review. Nutrients 2020, 12, 944. [CrossRef]

79. Morrison, D.J.; Preston, T. Formation of short chain fatty acids by the gut microbiota and their impact on human metabolism. Gut Microbes 2016, 7, 189-200. [CrossRef] [PubMed]

80. Fukumoto, S.; Tatewaki, M.; Yamada, T.; Fujimiya, M.; Mantyh, C.; Voss, M.; Eubanks, S.; Harris, M.; Pappas, T.N.; Takahashi, T. Short-chain fatty acids stimulate colonic transit via intraluminal 5-HT release in rats. Am. J. Physiol. Regul. Integr. Comp. Physiol. 2003, 284, R1269-R1276. [CrossRef]

81. Yano, J.M.; Yu, K.; Donaldson, G.P.; Shastri, G.G.; Ann, P.; Ma, L.; Nagler, C.R.; Ismagilov, R.F.; Mazmanian, S.K.; Hsiao, E.Y. Indigenous bacteria from the gut microbiota regulate host serotonin biosynthesis. Cell 2015, 161, 264-276. [CrossRef] [PubMed]

82. Esmaili, A.; Nazir, S.F.; Borthakur, A.; Yu, D.; Turner, J.R.; Saksena, S.; Singla, A.; Hecht, G.A.; Alrefai, W.A.; Gill, R.K. Enteropathogenic Escherichia coli infection inhibits intestinal serotonin transporter function and expression. Gastroenterology 2009, 137, 2074-2083. [CrossRef] [PubMed]

83. Yu, Y.; Yang, W.; Li, Y.; Cong, Y. Enteroendocrine cells: Sensing gut microbiota and regulating inflammatory bowel diseases. Inflamm. Bowel. Dis. 2020, 26, 11-20. [CrossRef] [PubMed]

84. Gribble, F.M.; Reimann, F. Enteroendocrine cells: Chemosensors in the intestinal epithelium. Annu. Rev. Physiol. 2016, 78, 277-299. [CrossRef] [PubMed]

85. Liñán-Rico, A.; Ochoa-Cortes, F.; Zuleta-Alarcon, A.; Alhaj, M.; Tili, E.; Enneking, J.; Harzman, A.; Grants, I.; Bergese, S.; Christofi, F.L. UTP-Gated signaling pathways of 5-HT release from BON Cells as a model of human enterochromaffin cells. Front. Pharmacol. 2017, 8, 429. [CrossRef] [PubMed]

86. Kim, M.; Cooke, H.J.; Javed, N.H.; Carey, H.V.; Christofi, F.; Raybould, H.E. D-glucose releases 5-hydroxytryptamine from human BON cells as a model of enterochromaffin cells. Gastroenterology 2001, 121, 1400-1406. [CrossRef] [PubMed]

87. Freeman, S.L.; Bohan, D.; Darcel, N.; Raybould, H.E. Luminal glucose sensing in the rat intestine has characteristics of a sodium-glucose cotransporter. Am. J. Physiol. Gastrointest. Liver Physiol. 2006, 291, G439-G445. [CrossRef] [PubMed]

88. Vincent, K.M.; Sharp, J.W.; Raybould, H.E. Intestinal glucose-induced calcium-calmodulin kinase signaling in the gut-brain axis in awake rats. Neurogastroenterol. Motil. 2011, 23, e282-e293. [CrossRef]

89. Merino, B.; Fernández-Díaz, C.M.; Cózar-Castellano, I.; Perdomo, G. intestinal fructose and glucose metabolism in health and disease. Nutrients 2019, 12, 94. [CrossRef] [PubMed]

90. Savastano, D.M.; Carelle, M.; Covasa, M. Serotonin-type 3 receptors mediate intestinal Polycose- and glucose-induced suppression of intake. Am. J. Physiol. Regul. Integr. Comp. Physiol. 2005, 288, R1499-R1508. [CrossRef]

91. Yoshikawa, T.; Inoue, R.; Matsumoto, M.; Yajima, T.; Ushida, K.; Iwanaga, T. Comparative expression of hexose transporters (SGLT1, GLUT1, GLUT2 and GLUT5) throughout the mouse gastrointestinal tract. Histochem. Cell Biol. 2011, 135, 183-194. [CrossRef]

92. Zelkas, L.; Raghupathi, R.; Lumsden, A.L.; Martin, A.M.; Sun, E.; Spencer, N.J.; Young, R.L.; Keating, D.J. Serotonin-secreting enteroendocrine cells respond via diverse mechanisms to acute and chronic changes in glucose availability. Nutr. Metab. 2015, 12, 55. [CrossRef]

93. Sumara, G.; Sumara, O.; Kim, J.K.; Karsenty, G. Gut-derived serotonin is a multifunctional determinant to fasting adaptation. Cell Metab. 2012, 16, 588-600. [CrossRef]

94. Liddle, R.A. Neuropods. Cell Mol. Gastroenterol. Hepatol. 2019, 7, 739-747. [CrossRef]

95. Ripken, D.; van der Wielen, N.; Wortelboer, H.M.; Meijerink, J.; Witkamp, R.F.; Hendriks, H.F. Nutrient-induced glucagon like peptide-1 release is modulated by serotonin. J. Nutr. Biochem. 2016, 32, 142-150. [CrossRef] 
96. Linden, D.R.; Chen, J.X.; Gershon, M.D.; Sharkey, K.A.; Mawe, G.M. Serotonin availability is increased in mucosa of guinea pigs with TNBS-induced colitis. Am. J. Physiol. Gastrointest. Liver Physiol. 2003, 285, G207-G216. [CrossRef] [PubMed]

97. O’Hara, J.R.; Lomax, A.E.; Mawe, G.M.; Sharkey, K.A. Ileitis alters neuronal and enteroendocrine signalling in guinea pig distal colon. Gut 2007, 56, 186-194. [CrossRef] [PubMed]

98. Kwon, Y.H.; Wang, H.; Denou, E.; Ghia, J.E.; Rossi, L.; Fontes, M.E.; Bernier, S.P.; Shajib, M.S.; Banskota, S.; Collins, S.M.; et al. Modulation of Gut Microbiota Composition by Serotonin Signaling Influences Intestinal Immune Response and Susceptibility to Colitis. Cell Mol. Gastroenterol. Hepatol. 2019, 7, 709-728. [CrossRef]

99. Yang, Y.; Zhu, X.; Qin, Y.; Chen, G.; Zhou, J.; Li, L.; Guan, J.; Ma, L.; Xue, Y.; Li, C. The anti-inflammatory effect of guchangzhixiepill by reducing colonic EC cell hyperplasia and serotonin availability in an ulcerative colitis rat model. Evid. Based Complement. Alternat Med. 2017, 2017, 8547257. [CrossRef] [PubMed]

100. Chen, M.; Gao, L.; Chen, P.; Feng, D.; Jiang, Y.; Chang, Y.; Jin, J.; Chu, F.F.; Gao, Q. Serotonin-exacerbated DSS-induced colitis is associated with increase in MMP-3 and MMP-9 expression in the mouse colon. Mediat. Inflamm. 2016, 2016, 5359768. [CrossRef] [PubMed]

101. Wheatcroft, J.; Wakelin, D.; Smith, A.; Mahoney, C.R.; Mawe, G.; Spiller, R. Enterochromaffin cell hyperplasia and decreased serotonin transporter in a mouse model of postinfectious bowel dysfunction. Neurogastroenterol. Motil. 2005, 17, 863-870. [CrossRef] [PubMed]

102. Shajib, M.S.; Wang, H.; Kim, J.J.; Sunjic, I.; Ghia, J.E.; Denou, E.; Collins, M.; Denburg, J.A.; Khan, W.I. Interleukin 13 and serotonin: Linking the immune and endocrine systems in murine models of intestinal inflammation. PLoS ONE 2013, 8, e72774. [CrossRef]

103. Zang, K.H.; Rao, Z.; Zhang, G.Q.; Qin, H.Y. Anticolitis activity of Chinese herbal formula yupingfeng powder via regulating colonic enterochromaffin cells and serotonin. Indian J. Pharmacol. 2015, 47, 632-637. [CrossRef]

104. Margolis, K.G.; Pothoulakis, C. Serotonin has a critical role in the pathogenesis of experimental colitis. Gastroenterology 2009, 137, 1562-1566. [CrossRef] [PubMed]

105. Margolis, K.G.; Stevanovic, K.; Li, Z.; Yang, Q.M.; Oravecz, T.; Zambrowicz, B.; Jhaver, K.G.; Diacou, A.; Gershon, M.D. Pharmacological reduction of mucosal but not neuronal serotonin opposes inflammation in mouse intestine. Gut 2014, 63, 928-937. [CrossRef]

106. Kim, J.J.; Wang, H.; Terc, J.D.; Zambrowicz, B.; Yang, Q.M.; Khan, W.I. Blocking peripheral serotonin synthesis by telotristat etiprate (LX1032/LX1606) reduces severity of both chemical- and infection-induced intestinal inflammation. Am. J. Physiol. Gastrointest. Liver Physiol. 2015, 309, G455-G465. [CrossRef]

107. Bischoff, S.C.; Mailer, R.; Pabst, O.; Weier, G.; Sedlik, W.; Li, Z.; Chen, J.J.; Murphy, D.L.; Gershon, M.D. Role of serotonin in intestinal inflammation: Knockout of serotonin reuptake transporter exacerbates 2,4,6-trinitrobenzene sulfonic acid colitis in mice. Am. J. Physiol. Gastrointest. Liver Physiol. 2009, 296, G685-G695. [CrossRef]

108. Xiao, J.; Shao, L.; Shen, J.; Jiang, W.; Feng, Y.; Zheng, P.; Liu, F. Effects of ketanserin on experimental colitis in mice and macrophage function. Int. J. Mol. Med. 2016, 37, 659-668. [CrossRef] [PubMed]

109. Kim, J.J.; Bridle, B.W.; Ghia, J.E.; Wang, H.; Syed, S.N.; Manocha, M.M.; Rengasamy, P.; Shajib, M.S.; Wan, Y.; Hedlund, P.B.; et al. Targeted inhibition of serotonin type 7 (5-HT7) receptor function modulates immune responses and reduces the severity of intestinal inflammation. J. Immunol. 2013, 190, 4795-4804. [CrossRef]

110. Zhang, Y.Z.; Li, Y.Y. Inflammatory bowel disease: Pathogenesis. World J. Gastroenterol. 2014, 20, 91-99. [CrossRef]

111. Cheng, H.Y.; Ning, M.X.; Chen, D.K.; Ma, W.T. Interactions between the gut microbiota and the host innate immune response against pathogens. Front. Immunol. 2019, 10, 607. [CrossRef]

112. Khan, W.I.; Ghia, J.E. Gut hormones: Emerging role in immune activation and inflammation. Clin. Exp. Immunol. 2010, 161, 19-27. [CrossRef] [PubMed]

113. Herr, N.; Bode, C.; Duerschmied, D. The effects of serotonin in immune cells. Front. Cardiovasc Med. 2017, 4, 48. [CrossRef] [PubMed]

114. Barbaro, M.R.; Di Sabatino, A.; Cremon, C.; Giuffrida, P.; Fiorentino, M.; Altimari, A.; Bellacosa, L.; Stanghellini, V.; Barbara, G. Interferon $\gamma$ is increased in the gut of patients with irritable bowel syndrome and modulates serotonin metabolism. Am. J. Physiol. Gastrointest. Liver Physiol. 2016, 310, G439-G447. [CrossRef]

115. Latorre, E.; Mendoza, C.; Matheus, N.; Castro, M.; Grasa, L.; Mesonero, J.E.; Alcalde, A.I. IL-10 modulates serotonin transporter activity and molecular expression in intestinal epithelial cells. Cytokine 2013, 61, 778-784. [CrossRef]

116. Kong, E.; Sucic, S.; Monje, F.J.; Savalli, G.; Diao, W.; Khan, D.; Ronovsky, M.; Cabatic, M.; Koban, F.; Freissmuth, M.; et al. STAT3 controls IL6-dependent regulation of serotonin transporter function and depression-like behavior. Sci. Rep. 2015, 5, 9009. [CrossRef]

117. Ruddell, R.G.; Mann, D.A.; Ramm, G.A. The function of serotonin within the liver. J. Hepatol. 2008, 48, 666-675. [CrossRef]

118. Papadimas, G.K.; Tzirogiannis, K.N.; Panoutsopoulos, G.I.; Demonakou, M.D.; Skaltsas, S.D.; Hereti, R.I.; Papadopoulou-Daifoti, Z.; Mykoniatis, M.G. Effect of serotonin receptor 2 blockage on liver regeneration after partial hepatectomy in the rat liver. Liver Int. 2006, 26, 352-361. [CrossRef]

119. Tzirogiannis, K.N.; Kourentzi, K.T.; Zyga, S.; Papalimneou, V.; Tsironi, M.; Grypioti, A.D.; Protopsaltis, I.; Panidis, D.; Panoutsopoulos, G.I. Effect of 5-HT7 receptor blockade on liver regeneration after 60-70\% partial hepatectomy. BMC Gastroenterol. 2014, 14, 201. [CrossRef] 
120. Balasubramanian, S.; Paulose, C.S. Induction of DNA synthesis in primary cultures of rat hepatocytes by serotonin: Possible involvement of serotonin S2 receptor. Hepatology 1998, 27, 62-66. [CrossRef]

121. Matondo, R.B.; Punt, C.; Homberg, J.; Toussaint, M.J.; Kisjes, R.; Korporaal, S.J.; Akkerman, J.W.; Cuppen, E.; de Bruin, A. Deletion of the serotonin transporter in rats disturbs serotonin homeostasis without impairing liver regeneration. Am. J. Physiol. Gastrointest. Liver Physiol. 2009, 296, G963-G968. [CrossRef]

122. Berger, M.; Gray, J.A.; Roth, B.L. The expanded biology of serotonin. Annu. Rev. Med. 2009, 60, 355-366. [CrossRef]

123. El-Merahbi, R.; Löffler, M.; Mayer, A.; Sumara, G. The roles of peripheral serotonin in metabolic homeostasis. FEBS Lett. 2015, 589, 1728-1734. [CrossRef]

124. Lefort, C.; Cani, P.D. The Liver under the spotlight: Bile acids and oxysterols as pivotal actors controlling metabolism. Cells 2021, 10, 400. [CrossRef] [PubMed]

125. Lin, B.; Morris, D.W.; Chou, J.Y. The role of HNF1alpha, HNF3gamma, and cyclic AMP in glucose-6-phosphatase gene activation. Biochemistry 1997, 36, 14096-14106. [CrossRef]

126. Rozenblit-Susan, S.; Chapnik, N.; Froy, O. Serotonin Prevents Differentiation of Brown Adipocytes by Interfering with Their Clock. Obesity (Silver Spring) 2019, 27, 2018-2024. [CrossRef]

127. Shong, K.E.; Oh, C.M.; Namkung, J.; Park, S.; Kim, H. Serotonin regulates de novo lipogenesis in adipose tissues through serotonin receptor 2A. Endocrinol. Metab. 2020, 35, 470-479. [CrossRef] [PubMed]

128. Kraemer, F.B.; Shen, W.J. Hormone-sensitive lipase: Control of intracellular tri-(di-)acylglycerol and cholesteryl ester hydrolysis. J. Lipid. Res. 2002, 43, 1585-1594. [CrossRef]

129. Siddiqui, J.A.; Partridge, N.C. Physiological bone remodeling: Systemic regulation and growth factor involvement. Physiology 2016, 31, 233-245. [CrossRef]

130. Kobayashi, Y.; Uehara, S.; Udagawa, N.; Takahashi, N. Regulation of bone metabolism by Wnt signals. J. Biochem. 2016, 159, 387-392. [CrossRef]

131. Cui, Y.; Niziolek, P.J.; MacDonald, B.T.; Zylstra, C.R.; Alenina, N.; Robinson, D.R.; Zhong, Z.; Matthes, S.; Jacobsen, C.M.; Conlon, R.A.; et al. Lrp5 functions in bone to regulate bone mass. Nat. Med. 2011, 17, 684-691. [CrossRef]

132. Williams, B.O. LRP5: From bedside to bench to bone. Bone 2017, 102, 26-30. [CrossRef]

133. Yadav, V.K.; Ducy, P. Lrp5 and bone formation: A serotonin-dependent pathway. Ann. N. Y. Acad. Sci. 2010, 1192, 103-109. [CrossRef] [PubMed]

134. Yadav, V.K.; Ryu, J.H.; Suda, N.; Tanaka, K.F.; Gingrich, J.A.; Schütz, G.; Glorieux, F.H.; Chiang, C.Y.; Zajac, J.D.; Insogna, K.L.; et al. Lrp5 controls bone formation by inhibiting serotonin synthesis in the duodenum. Cell 2008, 135, 825-837. [CrossRef]

135. Erjavec, I.; Bordukalo-Niksic, T.; Brkljacic, J.; Grcevic, D.; Mokrovic, G.; Kesic, M.; Rogic, D.; Zavadoski, W.; Paralkar, V.M.; Grgurevic, L.; et al. Constitutively elevated blood serotonin is associated with bone loss and Type 2 diabetes in rats. PLoS ONE 2016, 11, e0150102. [CrossRef]

136. Blazevic, S.; Erjavec, I.; Brizic, M.; Vukicevic, S.; Hranilovic, D. Molecular background and physiological consequences of altered peripheral serotonin homeostasis in adult rats perinatally treated with tranylcypromine. J. Physiol. Pharmacol. 2015, 66, 529-537. [PubMed]

137. Yadav, V.K.; Balaji, S.; Suresh, P.S.; Liu, X.S.; Lu, X.; Li, Z.; Guo, X.E.; Mann, J.J.; Balapure, A.K.; Gershon, M.D.; et al. Pharmacological inhibition of gut-derived serotonin synthesis is a potential bone anabolic treatment for osteoporosis. Nat. Med. 2010, 16, 308-312. [CrossRef]

138. Inose, H.; Zhou, B.; Yadav, V.K.; Guo, X.E.; Karsenty, G.; Ducy, P. Efficacy of serotonin inhibition in mouse models of bone loss. J. Bone Miner. Res. 2011, 26, 2002-2011. [CrossRef]

139. Yadav, V.K.; Oury, F.; Suda, N.; Liu, Z.W.; Gao, X.B.; Confavreux, C.; Klemenhagen, K.C.; Tanaka, K.F.; Gingrich, J.A.; Guo, X.E.; et al. A serotonin-dependent mechanism explains the leptin regulation of bone mass, appetite, and energy expenditure. Cell 2009, 138, 976-989. [CrossRef]

140. Kode, A.; Mosialou, I.; Silva, B.C.; Rached, M.T.; Zhou, B.; Wang, J.; Townes, T.M.; Hen, R.; DePinho, R.A.; Guo, X.E.; et al. FOXO1 orchestrates the bone-suppressing function of gut-derived serotonin. J. Clin. Investig. 2012, 122, 3490-3503. [CrossRef]

141. Chabbi-Achengli, Y.; Coudert, A.E.; Callebert, J.; Geoffroy, V.; Côté, F.; Collet, C.; de Vernejoul, M.C. Decreased osteoclastogenesis in serotonin-deficient mice. Proc. Natl. Acad. Sci. USA 2012, 109, 2567-2572. [CrossRef] 